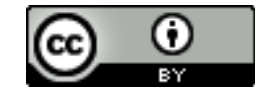

Esta obra está sob o direito de Licença Creative Commons Atribuição 4.0 Internacional.

\title{
AVALIAÇÃO EDUCACIONAL SOB VÁRIOS OLHARES
}

\author{
Divanise Maria de Souza Ferreira ${ }^{1}$ \\ Luciano Canuto Jacinto ${ }^{2}$ \\ Rosicleide Santos da Silva ${ }^{3}$ \\ Betijane Soares de Barros ${ }^{4}$
}

\section{RESUMO}

Introdução: A avaliação educacional é uma temática que atualmente vem sendo muito debatida, a mesma acontece para atender a objetivos e metas que indicam a qualidade da educação. Objetivo: Analisar os processos avaliativos e a ações pós avaliação. Metodologia: Trata-se de uma revisão sistemática integrativa. Os descritores livres Evaluation, Basic Education e Results, foram utilizados nas varreduras das seguintes bases de busca: SciELO, LILACS, Periódicos da CAPES, ScienceDirect, MEDLINE e Wiley. O período de coleta dos dados compreendeu em 20 e 24 de março de 2020. Com o critério de inclusão, texto completo, artigo de revisão, artigo original, revista relacionada e assuntos educacionais dos últimos cinco anos e exclusão Livros, monografias, TCC, resumos, reses, dissertações, artigos publicados há mais de seis anos e demais temas que não abordem assuntos educacionais. Resultados: Foram encontrados 17.431, analisados 172 trabalhos, mas os critérios de inclusão foram obtidos em apenas 24 artigos científicos, onde de acordo as etapas de revisão integrativa eram os que tratavam explicitamente de avaliação e eram estudos originais decorrente científicos, publicados entre 2016 e 2020. As categorias temáticas desenvolvida de acordo com a análise dos trabalhos se caracterizou em: 1- A avaliação educacional; 2- A avaliação em larga escala; 3- Modelos de avaliação; 4- Concepções sobre avaliação; 5- Bases legais e teóricas da avaliação. Discursão: A análise sobre o processo avaliativo deve levar em consideração a realidade, visando o êxito do ensino aprendizagem.

Palavras-chave: Avaliação. Educação básica e Resultados.

\footnotetext{
${ }^{1}$ divanisemaria@hotmail.com

2 lucianocanutojacinto11@gmail.com

3 cleidecajueiro@hotmail.com

${ }^{4}$ bj.sb@hotmail.com
} 


\section{RESUME}

Introduction: Educational assessment is a topic that is currently being much debated, the same happens to meet objects and goals developed by a specific school unit. Objective: To analyze the evaluation and the various objectives to be achieved through the evaluation processor. Methodology: This is an integrative systematic review. The free descriptors Evaluation, Basic Education and Results were used in the scans of the following search bases: SciELO, LILACS, CAPES journals, ScienceDirect, MEDLINE and Wiley. The period of data collection comprised on 20 and 24 March 2020. With the inclusion criteria, full text, review article, original article, related magazine and educational subjects of the last five years and exclusion Books, monographs, TCC, abstracts, reviews, dissertations, articles published more than six years ago and other topics that do not address educational issues. Results: 17,431 were found, 172 studies were analyzed, but the inclusion criteria were obtained in only 24 scientific articles, where according to the integrative review stages were those that explicitly dealt with evaluation and were original scientific studies, published between 2016 and 2020 The thematic categories developed according to the analysis of the works were characterized by: 1- Educational evaluation; 2- Large-scale evaluation; 3- Conceptions about evaluation. Discourse: The analysis of the evaluation process must take into account reality, aiming at the success of teaching and learning.

Keywords: Evaluation. Basic Education and Results. 


\section{INTRODUÇÃOO}

Desde em 1990, vem acontecendo uma expansão cada vez mais visível no que se diz respeito a avaliação. $\mathrm{O}$ Brasil tem sido um laboratório amplo e moderno na seara educacional, todas as etapas da educação básica são alvos disponíveis de averiguação e comparações através de avaliações externas. Os dados estatísticos retratam avanços, porém, muita desigualdade entre os estados, municípios e escolas brasileiras. Há uma grande divergência entre qualidade e os números apresentados pelos indicadores produzidos pelas unidades escolares e sistemas educacionais. Pode-se constatar essas resultados em sites como, o Instituto Nacional de Estudos e Pesquisas - INEP, Censo, Exame Nacional de Desempenho dos Estudante, ENAD e confirmar o quão são diversificados e inconstantes os indicadores gerados pelos processos avaliativos.

A reprovação, a evasão, a indisciplina e o abandono escolar estão diretamente relacionados ao fracasso escolar, é muito fácil realizar a avaliação diagnóstica para a obter esses dados, o grande percalço é criar ações efetivas para amenizar, quiçá eliminar esses indicadores que levam ao fracasso. Já se fez muito para melhorar esse quadro e mesmo assim o Brasil continua sendo destaque na produção de índices negativos, entre estes se sobressai a alta taxa de analfabetismo, ou melhor é o primeiro no ranking do analfabetismo. Vale salientar o contexto educacional da região Nordeste, recordista em ocupar as piores posições sociais, essa população tem uma história com marcas profundas de conformismo, autocondenação, miséria, incultura, fracasso e um enorme complexo de inferioridade e estigmas. A baixa proficiência em língua portuguesa e matemática é numericamente gerada pelas avaliações padronizadas em larga escala, aplicadas em todos as escolas do país, sem levar em conta a diversidade contexto social, político e econômico. É mister considerar a multivariação de contextos no território brasileiro, em seu amplo desnível de aprendizagem e fluxo escolar, Girotto (2019) com base no artigo $206 \mathrm{da}$ Constituição Federal, pressupõe que as redes de ensino tem condições de oferecer e garantir qualidade e equidade educacional, o autor sugere que haja uma política de avaliação, também, multivariável que atenda as especificidades de cada contexto.

A LDB 9394/96, art. 24, V, aborda a avaliação como verificação do rendimento escolar, podendo ser contínua e cumulativa, considerando os aspectos qualitativos e quantitativos, haja vista que o quantitativo não deve se sobressair. Abrange toda a Educação básica inclui a educação infantil, 
ensino fundamental e ensino médio. A nação brasileira apresenta um quadro com marcas profundas de fracasso escolar. A mídia divulga resultados em forma de números, e na maioria das vezes ocultam a realidade social e econômica dos indivíduos e das instituições escolares avaliadas.

De acordo com a BNCC - Base Nacional Comum Curricular, avaliação é uma atividade processual que norteia toda a prática pedagógica, a partir de didáticas, métodos e embasamentos teóricos condizentes com o objetivo que se pretende alcançar, cabendo ao professor a tarefa de adequar instrumentos efetivos no percurso desse processo. Para uma boa aplicabilidade do processo avaliativo é importante conhecer a temática, estar alinhado com a realidade dos estudantes, interagir com os importantes teóricos, adotar uma tendência pedagógica que ofereça pressupostos para uma ação didática significativa.

No dicionário da língua portuguesa Michaelis avaliar é "calcular ou determinar o valor, o preço ou o merecimento de:" é exatamente essa a concepção da maioria dos profissionais da educação. Avalia-se de uma forma mais restrita, na sala de aula, apenas as habilidades e competências necessárias para a realização de provas, apenas o cognitivo, fugindo totalmente do verdadeiro sentido e propósito da ação de avaliar e o mesmo se repete nas demais modalidades de avaliação. Figueiredo et al.
(2018), tecem uma crítica ao formato e aos instrumentos utilizados pata e obter o Índice de Desenvolvimento da Educação Básica IDEB e afirmam que os resultados são inconsistentes e incoerentes, pois apenas os números não revelam o verdadeiro retrato educacional.

Até a implementação da BNCC foi percorrido um longo caminho, sendo necessário a modernização da educação no que diz respeito a avaliação e os mecanismos e ferramentas utilizados pelos avaliadores seja um professor ou um sistema. Diante disso em 2005 teve início o processo de reestruturação, transformando o Sistema de Avaliação da Educação Básica - SAEB, É instituída a Avaliação Nacional do Rendimento Escolar - ANRESC, conhecida como Prova Brasil, uma avaliação censitária com o objetivo de atender alunos da $4^{\mathrm{a}}$ série $/ 5^{\mathrm{o}}$ ano $\mathrm{e}$ $8^{\mathrm{a}}$ série $/ 9^{\circ}$ ano do ensino fundamental das escolas públicas, promovida, financiada e monitorada pelo Ministério da Educação e Cultura - MEC. As mesmas utilizam mecanismos e ferramentas para produzir indicadores e apresentar a realidade do contexto educacional brasileiro. Mais a diante surge a Avaliação Nacional da Alfabetização - ANA passa a compor também o SAEB, o público alvo são alunos do $3^{\circ}$ Ano do ensino fundamental das escolas públicas, e a Avaliação Nacional da Educação Básica - ANEB, avaliando por 
amostragem a $3^{\mathrm{a}}$ série do ensino médio, nessa modalidade a avaliação se estende também as escolas privadas. Hoje todas as nomenclaturas dadas a avaliação da educação básica se resume em SAEB.

$\mathrm{O}$ ensino superior começou a ser organizado entre as décadas de 50 e 70 , se expandiu nos anos 90 e diante da busca pela escolarização e do aumento da quantidades de instituições foi preciso regulamentar uma política de avaliação. Eram realizados exames para medir a eficiência e a eficácia, ou seja, a qualidade dessa modalidade de ensino. $\mathrm{O}$ modelo inicial de avaliação foi o Provão nos anos 1990 que evoluiu para Sistema Nacional de Avaliação do Ensino Superior - SINAES tendo como objetivos avaliar os cursos de graduação, a instituição e o desempenho dos estudantes mediante a aplicação do Exame Nacional de Desempenho dos Estudantes - ENADE.

Vive-se dias confusos, uma sociedade capitalista e competitiva, de um lado tem uma classe que considera a educação como a principal ferramenta para mudar o mundo sendo a prática pedagógica capaz de formar cidadãos críticos, capazes de construir uma nação mais justa e igualitária. De outro lado vê-se outra classe manipuladora e opressora, usando a educação para gerar renda formando indivíduos para o mercado de trabalho. Enquanto uma classe tem como objetivo conquistar a promessa de dias melhores, outros tem como objetivo interesses políticos lucrativos para fortalecer a hegemonia. Certamente o bônus irá para a segunda classe citada, deixando a esperança de dias melhores para um tempo futuro muito distante.

Para Vieira \& Côco (2016), há uma fragmentação na prática da avaliativa em larga escala, pois a Educação Infantil tem sido excluída, uma vez que é parte do todo, deveria participar como as outras etapas, utilizando os mesmos critérios, inclusive o modelo padronizado de teste e a produção se indicadores. Assim, se consolidaria de fato a integração da educação básica, tendo um produto final completo facilitando a análise de especialistas para elencar propostas visando melhorias.

A cada biênio, em todos os anos ímpares, vivencia-se uma corrida ao pódio, no final como a nação brasileira, especialmente, o Nordeste, destaca-se negativamente, e passa a ser alvo de severas e injustas críticas. Tratando das avaliações externas, existe uma organização hierárquica, associado a quem recebe os bônus e quem recebe os ônus. Daí surge uma série de questionamentos. Quem cria e institui as metas? Quem financia? Quem executa? Para que executa? O que acontece com quem consegue alcançar o que foi projetado e com quem não consegue? $\mathrm{E}$ quem regride? Para Unterhalter (2019) é preciso perguntar e compreender como as 
pessoas se sentem antes, durante e após o período de avaliação, se estão preparados, se desejam ser avaliados ou de qual forma podem ser avaliados.

A Organização de Cooperação e Desenvolvimento Econômico - OCDE, promove e avalia os sistemas de avaliação de mais de quarenta países, incluindo o Brasil, a avaliação é padronizada e norteada pela política de competências, os estudantes devem ter o conhecimento básico em leitura, interpretação, resolução de problemas e raciocínio lógico. Para a OCDE o país que consegue um bom desempenho consegue garantir mecanismos de coesão e adaptação social, pois o indivíduo em boa situação social é importante para o fortalecimento da hegemonia política, diz Pereira (2017).

Gestores escolares, professores e estudantes frequentes, ou seja, comparecem à escola todos os dias, mesmo assim muitos discentes são reprovados e muitas instituições produzem resultados educacionais negativos. É lamentável, mas diante do quadro caótico que se encontra a educação muito se questiona sobre o trabalho que é desenvolvido no cotidiano escolar, daí a importância da avaliação institucional. De acordo com Sílveres e para a mudança ser efetiva é fundamental seguir três etapas início, implementação e continuidade ou institucionalização Fullan, 2009 citado por Santos (2018), o inicio tem a ver com a tomada de decisão, a implementação é a execução, é fazer a mudança acontecer e a continuação é quando a mudança passa a fazer parte da rotina.

Nesse cenário surge a necessidade de uma pessoa capacitada para gerir um sistema, uma rede, uma escola, inovando a concepção sobre o perfil de uma gestão educacional, capaz de articular o trabalho administrativo, o pedagógico e participação de todos. A necessidade, a clareza, a complexidade e a qualidade ou praticidade da inovação devem ser levadas em consideração no processo de mudança, bem como os fatores externos a escola. Sílveres \& Santos (2017), salientam que jamais deve-se impor a mudança, mesmo que alguns dos envolvidos tenham dificuldade de adaptação, ela tem que acontecer mediante uma necessidade e para que tenha êxito deve ser planejada. Uma forma impositiva de avaliação é, por exemplo, a que é realizada pelo Programa Internacional de Avaliação de Estudantes, e os resultados são catastróficos.

Diagnosticar, ofertar as condições mínimas para o trabalho, fomentar o trabalho coletivo, implantar uma prática avaliativa significativa, utilizar instrumentos adequados, são critérios fundamentais para um trabalho docente. Além de gerar reflexão, promove a conscientização sobre a função e o papel de 
cada um dos envolvidos, substituindo os modelos impostos por modelos reais e aplicáveis. Contudo, as metas previstas nos documentos que regem a educação brasileira precisam ser atingidas, os indicadores, tanto local quanto global, devem de fato expressar qualidade $\mathrm{e}$ igualdade, como estabelece o Sustainable Development Goal - SGD4. Falta um diagnóstico real e atual do cotidiano da escola para que o resultado da avaliação seja real e mais justo, é o que defende Unterhalter (2019).

São inúmeros os métodos, técnicas, instrumentos e ferramentas para incrementar a ação pedagógica e garantir avanços, entre elas as tecnologias. Atualmente, é inadmissível um professor se apoiar, unicamente, na tendência tradicional. A sociedade contemporânea, informatizada e informada, necessita de uma escola que atenda seus anseios. Vale salientar que hoje a tecnologia é uma grande aliada para a melhoria da aprendizagem, Santos \& Alves (2017) apontam que o uso das Tecnologias da Informação e da

\section{METODOLOGIA}

Revisão bibliográfica do tipo sistemática integrativa estruturados em 6 etapas; a $1^{\circ}$ é referente ao tema e a pergunta norteadora e ao objetivo, estratégias de buscas, descritores, biblioteca virtuais na $2^{\circ}$
Comunicação - TICs pode contribuir na participação, na diversidade de atividades e práticas e até na motivação dos estudantes. Sabendo que na BNCC a quinta competência geral visa o desenvolvimento da cultura digital.

Pode-se afirmar que os indicadores em sua essência contribuem para alavancar a qualidade da aprendizagem, então deve-se estabelecer metas e objetivos atingíveis, de modo que todos os envolvidos se sintam estimulados e comprometidos com o processo. A escola, a rede, o sistema devem ser norteados pelo diagnóstico de sua clientela, que por sinal está cada vez mais diversificada, tecnologicamente informada e proativa, como também pelo contexto social-político-econômico vigente. A avaliação deve estar a favor das melhorias, o saber popular e o científico devem caminhar juntos, a teoria aliada à prática e a diversidade cultural sendo valorizada. Em outras palavras o planejamento, as ações, as metas são indissociáveis e devem estar bem articuladas com a rotina escolar.

aconteceu a coleta de dados os critérios, na $3^{\circ}$ busca por trabalhos relacionados nas $4^{\circ}$ categorias obtidas, no $5^{\circ}$ análise, discursões e resultados e na $6^{\circ}$ apresentação da revisão (Quadro 1). 
Quadro 1 - Detalhamento das etapas da Revisão Sistemática Integrativa

\begin{tabular}{|c|c|c|c|c|}
\hline ETAPA & $\begin{array}{l}\text { TÓPICOS DE } \\
\text { CADA ETAPA }\end{array}$ & \multicolumn{3}{|c|}{ DETALHAMENTO DE CADA ETAPA } \\
\hline \multirow[t]{18}{*}{$1^{\mathrm{a}}$} & Tema & \multicolumn{3}{|c|}{ Avaliação educacional sob vários olhares } \\
\hline & $\begin{array}{l}\text { Pergunta } \\
\text { norteadora }\end{array}$ & \multicolumn{3}{|c|}{ Avaliação está voltada para atender a quem? } \\
\hline & Objetivo geral & \multicolumn{3}{|c|}{ Analisar a avaliação através dos mais diversos ângulos. } \\
\hline & Estratégia de busca & \multicolumn{3}{|c|}{$\begin{array}{l}\text { 1. Cruzamento de descritores por meio do operador } \\
\text { booleano AND; } \\
2 . \quad \text { Uso de aspas nos politermos (descritor com mais de } \\
\text { um termo) para que a varredura de artigos científicos } \\
\text { contemplasse o termo exato; } \\
\text { 3. Uso de descritores estruturados (codificação) no } \\
\text { DECS ou MESH; } \\
4 . \quad \text { Uso de metadados (filtros) nas bibliotecas virtuais; } \\
5 \text { Uso de descritores em inglês para ampliar o número } \\
\text { de artigos. }\end{array}$} \\
\hline & \multirow{3}{*}{$\begin{array}{ll}\text { Banco } & \mathrm{de} \\
\text { terminologias } & \end{array}$} & Banco & \multicolumn{2}{|c|}{ Link } \\
\hline & & DeCS & \multirow{2}{*}{\multicolumn{2}{|c|}{$\begin{array}{l}\text { http://decs.bvs.br/ } \\
\text { https://www.ncbi.nlm.nih.gov/mesh }\end{array}$}} \\
\hline & & $\mathrm{MeSH}$ & & \\
\hline & \multirow[t]{4}{*}{$\begin{array}{l}\text { Descritores livres e } \\
\text { estruturados }\end{array}$} & Descritor & DeCS (registro) & $\begin{array}{l}\text { MeSH (identificador } \\
\text { único) }\end{array}$ \\
\hline & & Evaluation & D019091 & D005069 \\
\hline & & Basic education & DDCS035173 & D004493 \\
\hline & & Results & D005188 & D003933 \\
\hline & \multirow[t]{7}{*}{ Bibliotecas virtuais } & Bibliotecas & \multicolumn{2}{|l|}{ Links } \\
\hline & & 1. Wiley; & \multicolumn{2}{|c|}{ https://onlinelibrary.wiley.com/ } \\
\hline & & $\begin{array}{l}\text { 2. ScienceDirect } \\
\text {; }\end{array}$ & \multicolumn{2}{|c|}{ https://www.sciencedirect.com/ } \\
\hline & & 3. MEDLINE; & \multicolumn{2}{|c|}{ http://bases.bireme.br/ } \\
\hline & & 4. SciELO; & \multicolumn{2}{|c|}{ https://search.scielo.org/ } \\
\hline & & $\begin{array}{l}\text { 5. Periódicos da } \\
\text { CAPES }\end{array}$ & \multicolumn{2}{|c|}{ https://www.periodicos.capes.gov.br/ } \\
\hline & & 6. LILACS & \multicolumn{2}{|c|}{ https://lilacs.bvsalud.org/ } \\
\hline \multirow[t]{3}{*}{$2^{a}$} & $\begin{array}{l}\text { Período de coleta } \\
\text { de dados }\end{array}$ & \multicolumn{3}{|c|}{20 a 24 de março de 2020.} \\
\hline & Critério de inclusão & \multicolumn{3}{|c|}{$\begin{array}{l}\text { Texto completo: artigo de revisão, artigo original, revista } \\
\text { relacionada e assuntos educacionais dos últimos cinco anos. }\end{array}$} \\
\hline & $\begin{array}{l}\text { Critérios } \\
\text { exclusão }\end{array}$ & \multicolumn{3}{|c|}{$\begin{array}{l}\text { Livros, monografias, TCC, resumos, reses, dissertações, } \\
\text { artigos publicados há mais de seis anos e demais temas que } \\
\text { não abordem assuntos educacionais. }\end{array}$} \\
\hline
\end{tabular}




\begin{tabular}{|c|c|c|}
\hline $3^{\mathrm{a}}$ & $\begin{array}{l}\text { Número } \\
\text { trabalhos } \\
\text { selecionados para } \\
\text { revisão sistemática } \\
\text { integrativa a partir } \\
\text { da leitura dos } \\
\text { agentes } \\
\text { indexadores das } \\
\text { publicações } \\
\text { (resumo, palavras- } \\
\text { chave e título) e } \\
\text { resultados, os quais } \\
\text { devem conter os } \\
\text { descritores } \\
\text { utilizados neste } \\
\text { estudo }\end{array}$ & 23 \\
\hline $4^{\mathrm{a}}$ & $\begin{array}{l}\text { Categorias obtidas } \\
\text { com a análise dos } \\
\text { trabalhos } \\
\text { científicos } \\
\text { investigados }\end{array}$ & $\begin{array}{l}\text { 1- } \quad \text { A avaliação educacional; } \\
\text { 2- } \quad \text { A avaliação em larga escala; } \\
\text { 3- } \quad \text { Concepções sobre avaliação; }\end{array}$ \\
\hline $5^{\mathrm{a}}$ & $\begin{array}{lr}\text { Analise, } & \\
\text { interpretação } & \mathrm{e} \\
\text { discursão } & \text { dos } \\
\text { resultados } & \end{array}$ & Ver em "Resultados e Discursão" \\
\hline $6^{\mathrm{a}}$ & $\begin{array}{l}\text { Apresentação da } \\
\text { revisão em formato } \\
\text { de artigo, o qual } \\
\text { contemple } \\
\text { propostas para } \\
\text { estudos futuros. }\end{array}$ & Esse Artigo completo. \\
\hline
\end{tabular}

RESULTADOS

A busca resultou em 17.431 publicações científicas nos bancos de dados, das quais 172 eram artigos científicos disponíveis após o uso dos filtros, 23 que atenderam aos critérios de inclusão (Quadro 2), sendo submetidos às etapas da revisão integrativa (Quadro 3). 
Quadro 2. Detalhamento do processo de busca dos artigos: string de busca, base de dados e quantitativo de artigos.

\begin{tabular}{|c|l|c|c|c|}
\hline \multirow{2}{*}{$\begin{array}{c}\text { String de } \\
\text { busca }\end{array}$} & Bases de dados & $\begin{array}{c}\text { Total de } \\
\text { publicações } \\
\text { sem o filtro }\end{array}$ & $\begin{array}{c}\text { Publicações } \\
\text { disponíveis após } \\
\text { aplicar os filtros }\end{array}$ & $\begin{array}{c}\text { Publicações } \\
\text { aproveitadas } \\
\text { na Revisão } \\
\text { Sistemática } \\
\text { Integrativa }\end{array}$ \\
\hline \multirow{4}{*}{$\begin{array}{c}\text { evaluation } \\
\text { AND basic } \\
\text { education } \\
\text { AND results }\end{array}$} & SciELO & 23 & 11 & 10 \\
\cline { 2 - 5 } & LILACS & 75 & 2 & 0 \\
\cline { 2 - 5 } & ScionceDirect & 5048 & 53 & 11 \\
\cline { 2 - 5 } & MEDLINE & 0 & 43 & 0 \\
\cline { 2 - 5 } & Wiley & 4.115 & 0 & 1 \\
\hline & Total & 17.431 & 172 & 23 \\
\hline
\end{tabular}

Fonte: Autoria própria.

Quadro 3. Artigos selecionados para confecção do trabalho: autores, título, link para acesso, descritores, data de publicação e conclusão do trabalho.

\begin{tabular}{|c|c|c|c|c|c|c|}
\hline $\mathbf{N}^{\mathbf{o}}$ & Autor(a) & Tema & Link da publicação & $\begin{array}{l}\text { Descritor } \\
\text { es }\end{array}$ & $\begin{array}{l}\text { Data } \\
\text { de } \\
\text { public } \\
\text { acão }\end{array}$ & $\begin{array}{c}\text { Conclusã } \\
\quad 0\end{array}$ \\
\hline 1 & $\begin{array}{l}\text { SÍVERES, L; } \\
\text { SANTOS, J. } \\
\text { R. R }\end{array}$ & $\begin{array}{l}\text { Avaliação } \\
\text { Institucional } \\
\text { na } \\
\text { Educação } \\
\text { básica: } \\
\text { Os desafios da } \\
\text { Implementaçã } \\
\text { o }\end{array}$ & $\underline{\text { http://dx.doi.org/10.1822 }}$ & $\begin{array}{l}\text { Avaliação } \\
\text { institucional; } \\
\text { Educação } \\
\text { Básica; } \\
\text { Gestão } \\
\text { democrática; } \\
\text { Implementaç } \\
\text { ão; }\end{array}$ & $\begin{array}{l}30 / 01 / 20 \\
18\end{array}$ & $\begin{array}{l}\text { Para que } \\
\text { processo de } \\
\text { avaliação } \\
\text { seja efetivo } \\
\text { e provoque } \\
\text { mudanças } \\
\text { nos } \\
\text { indivíduos e } \\
\text { nas } \\
\text { instituições } \\
\text { é necessário } \\
\text { a } \\
\text { participação } \\
\text { e o } \\
\text { envolvimen } \\
\text { to de todos. }\end{array}$ \\
\hline 2 & $\begin{array}{l}\text { SANTOS, T. } \\
\text { P; ALVES, M. } \\
\text { P. }\end{array}$ & $\begin{array}{l}\text { O contributo } \\
\text { das } \\
\text { tecnologias no } \\
\text { desenvolvime } \\
\text { nto do } \\
\text { currículo } \\
\text { escolar: } \\
\text { perspectivas } \\
\text { dos alunos }\end{array}$ & $\begin{array}{l}\frac{\text { http://dx.doi.org/10.2172 }}{3 / \text { riaee.v12.n.esp.2.1030 }} \\
\underline{9}\end{array}$ & $\begin{array}{l}\text { Tecnologias } \\
\text { da } \\
\text { informação e } \\
\text { da } \\
\text { comunicaçã } \\
\text { o. } \\
\text { Ensino } \\
\text { básico. } \\
\text { Currículo } \\
\text { escolar. } \\
\text { Sucesso. }\end{array}$ & $\begin{array}{l}21 / 08 / 20 \\
17\end{array}$ & $\begin{array}{l}\text { Os } \\
\text { professores } \\
\text { precisam } \\
\text { inovar a } \\
\text { prática } \\
\text { pedagógica } \\
\text { fazendo uso } \\
\text { da } \\
\text { tecnologia. }\end{array}$ \\
\hline
\end{tabular}




\begin{tabular}{|c|c|c|c|c|c|c|}
\hline 3 & $\begin{array}{l}\text { SOUZA, R.R; } \\
\text { COLARES, A. } \\
\text { A }\end{array}$ & $\begin{array}{l}\text { A avaliação } \\
\text { em rarga } \\
\text { escala nos } \\
\text { centros } \\
\text { educacionais } \\
\text { de tempo } \\
\text { integral: mais } \\
\text { tempo, } \\
\text { melhores } \\
\text { resultados? }\end{array}$ & $\begin{array}{l}\frac{\text { http://dx.doi.org/10.1867 }}{5 / 1981-} \\
\underline{\underline{8106 . v o l 27 . n 56 . p 511-}}\end{array}$ & $\begin{array}{l}\text { Avaliação } \\
\text { em larga } \\
\text { escala. } \\
\text { Tempo } \\
\text { integral. } \\
\text { Qualidade. }\end{array}$ & $\begin{array}{l}20 / 12 / 20 \\
17\end{array}$ & $\begin{array}{l}\text { O Centro } \\
\text { Educacional } \\
\text { de Tempo } \\
\text { Integral em } \\
\text { análise, } \\
\text { desenvolve } \\
\text { u um } \\
\text { trabalho } \\
\text { significativ } \\
\text { o obtendo } \\
\text { um } \\
\text { resultado } \\
\text { satisfatório } \\
\text { na avaliação } \\
\text { em larga } \\
\text { escala. Mas } \\
\text { os } \\
\text { estudiosos } \\
\text { ressaltam } \\
\text { que atingir } \\
\text { metas } \\
\text { quantitativa } \\
\text { s não é } \\
\text { garantia de } \\
\text { qualidade. }\end{array}$ \\
\hline 4 & $\begin{array}{l}\text { SANTOS, F. } \\
\text { A; PETOUR, } \\
\text { M. T. F }\end{array}$ & $\begin{array}{l}\text { Internacionaliz } \\
\text { ação dos } \\
\text { sistemas de } \\
\text { avaliação: } \\
\text { evidências de } \\
\text { brasil e chile }\end{array}$ & $\begin{array}{l}\underline{\text { https://doi.org/10.21723/ }} \\
\underline{\text { riaee.v14iesp.3.12766 }}\end{array}$ & $\begin{array}{l}\text { Avaliação. } \\
\text { Internaciona } \\
\text { lização. } \\
\text { Chile. } \\
\text { Brasil. }\end{array}$ & $\begin{array}{l}30 / 08 / 20 \\
19\end{array}$ & $\begin{array}{l}\text { Enquanto as } \\
\text { escolas } \\
\text { assumem } \\
\text { toda a } \\
\text { responsabili } \\
\text { dade na } \\
\text { alimentação } \\
\text { dos sistemas } \\
\text { de } \\
\text { avaliação. A } \\
\text { elite } \\
\text { políticas de } \\
\text { diversos } \\
\text { contextos se } \\
\text { interessam } \\
\text { apenas } \\
\text { pelos } \\
\text { resultados. }\end{array}$ \\
\hline 5 & $\begin{array}{l}\text { OLVERA, A. } \\
\text { C; } \\
\text { GUTIÉRREZ, } \\
\text { J. A. L; } \\
\text { LOZANO, M. } \\
\text { E. E. C }\end{array}$ & $\begin{array}{l}\text { Los consejos } \\
\text { técnicos } \\
\text { escolares para } \\
\text { la inclusión y } \\
\text { equidad } \\
\text { educativa en la } \\
\text { educación } \\
\text { básica de } \\
\text { Tlaxcala, } \\
\text { México }\end{array}$ & $\begin{array}{l}\text { http://dx.doi.org/10.1535 } \\
\underline{9 / \text { ree.22-1.8 }}\end{array}$ & $\begin{array}{l}\text { Consejos } \\
\text { técnicos } \\
\text { escolares; } \\
\text { educación } \\
\text { básica; } \\
\text { gestión del } \\
\text { centro de } \\
\text { enseñanza; } \\
\text { Políticas } \\
\text { educativas; } \\
\text { inclusión y } \\
\text { equidad } \\
\text { educativa. }\end{array}$ & $\begin{array}{l}01 / 01 / 20 \\
18\end{array}$ & $\begin{array}{l}\text { O conselho } \\
\text { escolar deve } \\
\text { ser bem } \\
\text { definido e } \\
\text { planejado, } \\
\text { tendo em } \\
\text { vista que é } \\
\text { um } \\
\text { instrumento } \\
\text { avaliativo } \\
\text { onde o } \\
\text { qualitativo e } \\
\text { quantitativo } \\
\text { caminham } \\
\text { juntos. }\end{array}$ \\
\hline
\end{tabular}




\begin{tabular}{|c|c|c|c|c|c|c|}
\hline 6 & $\begin{array}{l}\text { PINT, M. L; } \\
\text { JUNG, H. S. } \\
\text { Y; } \\
\text { SUDBRACK, } \\
\text { E. M }\end{array}$ & $\begin{array}{l}\text { Evaluation } \\
\text { Policies and } \\
\text { Educational } \\
\text { Management: } \\
\text { articulations, } \\
\text { interfaces } \\
\text { and tensions }\end{array}$ & $\begin{array}{l}\text { http://dx.doi.org/10.1590 } \\
\underline{2175-623688386}\end{array}$ & $\begin{array}{l}\text { Educational } \\
\text { Management } \\
\text {. Evaluation } \\
\text { Policies. } \\
\text { Basic } \\
\text { Education. } \\
\text { Higher } \\
\text { Education. }\end{array}$ & $\begin{array}{l}26 / 09 / \\
2018\end{array}$ & $\begin{array}{l}\text { As políticas } \\
\text { de avaliação } \\
\text { do ensino } \\
\text { superior } \\
\text { também tem } \\
\text { como } \\
\text { objetivo } \\
\text { controlar e } \\
\text { limitar a } \\
\text { autonomia } \\
\text { das } \\
\text { instituições } \\
\text { de ensino } \\
\text { supeior. }\end{array}$ \\
\hline 7 & $\begin{array}{l}\text { WALLENIUS } \\
\text { JUVONEN, S; } \\
\text { JUVNSEN, P; } \\
\text { VARJO, J }\end{array}$ & $\begin{array}{l}\text { Schools, } \\
\text { accountability } \\
\text { and } \\
\text { Transparency } \\
\text { approaching } \\
\text { the Nordic } \\
\text { school } \\
\text { evaluation } \\
\text { practices } \\
\text { through } \\
\text { discursive } \\
\text { institutionalis } \\
\text { m }\end{array}$ & $\underline{\underline{\text { https://doi.org/10.1080/2 }}} \underline{\underline{0020317.2018 .1537432}}$ & $\begin{array}{l}\text { Educational } \\
\text { quality } \\
\text { assurance } \\
\text { and } \\
\text { evaluation; } \\
\text { Nordic } \\
\text { countries; } \\
\text { accountabilit } \\
\text { y; } \\
\text { transparency } \\
\text {; } \\
\text { discursive } \\
\text { institutionali } \\
\text { sm }\end{array}$ & $\begin{array}{l}11 / 12 / \\
2018\end{array}$ & $\begin{array}{l}\text { Os estudos } \\
\text { apontam o } \\
\text { uso que } \\
\text { cada país } \\
\text { faz dos } \\
\text { resultados } \\
\text { avaliativos. } \\
\text { Sugerindo } \\
\text { um debate } \\
\text { aberto para } \\
\text { a futura } \\
\text { formulação } \\
\text { de políticas } \\
\text { e mudanças } \\
\text { governamen } \\
\text { tais. Na } \\
\text { Finlândia, } \\
\text { por } \\
\text { exemplo, os } \\
\text { resultados } \\
\text { não são } \\
\text { divulgados } \\
\text { de forma } \\
\text { transparente } \\
\text { dificultando } \\
\text { debates e } \\
\text { reformulaçõ } \\
\text { es de es } \\
\text { ações. }\end{array}$ \\
\hline 08 & $\begin{array}{l}\text { ALMEIDA, } \\
\text { M. L. P; } \\
\text { JUNG, H. S; } \\
\text { SUDBRACK, } \\
\text { E. M }\end{array}$ & $\begin{array}{l}\text { Políticas } \\
\text { educacionales } \\
\text { brasileñas: } \\
\text { consecuencias } \\
\text { de un currículo } \\
\text { nacional }\end{array}$ & $\begin{array}{l}\text { https://doi.org/10.24320/ } \\
\underline{\text { redie.2019.21.e02.1784 }}\end{array}$ & $\begin{array}{l}\text { Política } \\
\text { educacional; } \\
\text { Evaluación } \\
\text { del } \\
\text { currículum; } \\
\text { Pertinencia } \\
\text { del plan de } \\
\text { estúdios; } \\
\text { Educación } \\
\text { básica. }\end{array}$ & $\begin{array}{l}20 / 07 / 20 \\
17\end{array}$ & $\begin{array}{l}\text { Os autores } \\
\text { não } \\
\text { conseguem } \\
\text { chegar a } \\
\text { uma } \\
\text { conclusão, } \\
\text { mas } \\
\text { afirmam } \\
\text { que } \\
\text { BNCC a } \\
\text { uma } \\
\text { imposição e } \\
\text { que } \\
\text { currículo é } \\
\text { excludente e } \\
\text { todas as } \\
\text { ações do }\end{array}$ \\
\hline
\end{tabular}

Ferreira et al. 


\begin{tabular}{|c|c|c|c|c|c|c|}
\hline & & & & & & $\begin{array}{l}\text { governo } \\
\text { visam o } \\
\text { fortalecime } \\
\text { nto da } \\
\text { hegemonia } \\
\text { liberal. }\end{array}$ \\
\hline 09 & $\begin{array}{l}\text { FILHO, O. O; } \\
\text { SÁ, V. I. M. }\end{array}$ & $\begin{array}{l}\text { Avaliação } \\
\text { externa da } \\
\text { gestão escolar } \\
\text { do Programa } \\
\text { Nova Escola } \\
\text { do Estado } \\
\text { do Rio de } \\
\text { Janeiro: um } \\
\text { estudo } \\
\text { reflexivo sobre } \\
\text { o seu primeiro } \\
\text { ciclo } \\
\text { de realização } \\
\text { (2000-2003), } \\
\text { passados } \\
\text { quinze anos de } \\
\text { sua } \\
\text { implementaçã } \\
\text { o }\end{array}$ & $\begin{array}{l}\underline{\text { https://doi.org/10.1590/S }} \\
\underline{0104-} \\
\underline{40362016000200002}\end{array}$ & $\begin{array}{l}\text { Avaliação. } \\
\text { Gestão } \\
\text { escolar. } \\
\text { Nova } \\
\text { Escola. }\end{array}$ & $\begin{array}{l}\text { Jun/ } 201 \\
6\end{array}$ & $\begin{array}{l}\text { A gestão é } \\
\text { avaliada, } \\
\text { mas o } \\
\text { resultado } \\
\text { ainda não é } \\
\text { utilizado } \\
\text { devidament } \\
\text { e pelos } \\
\text { avaliadores. } \\
\text { O neoliberalis } \\
\text { mo é } \\
\text { alimentado } \\
\text { gerando um } \\
\text { conflito } \\
\text { entre a } \\
\text { democratiza } \\
\text { ção e a } \\
\text { educação } \\
\text { contemporâ } \\
\text { nea. }\end{array}$ \\
\hline 10 & $\begin{array}{lr}\text { FIGUEIRED } \\
\text { O, } & \text { D; } \\
\text { CARMO, } & \text { E; } \\
\text { MAIA, } & \text { R.; } \\
\text { SILVA. L } & \end{array}$ & $\begin{array}{l}\text { Os cavalos } \\
\text { também caem: } \\
\text { Tratado } \\
\text { das } \\
\text { inconsistência } \\
\text { s do IDEB }\end{array}$ & $\begin{array}{l}\text { https://doi.org/10.1590/S } \\
\underline{0104-} \\
\underline{403620180026001178}\end{array}$ & $\begin{array}{l}\text { Avaliação. } \\
\text { Educação } \\
\text { básica. } \\
\text { Ensino } \\
\text { público. } \\
\text { IDEB }\end{array}$ & set. 2018 & $\begin{array}{l}\text { Elevar o } \\
\text { Índice de } \\
\text { Desenvolvi } \\
\text { mento da } \\
\text { Educação } \\
\text { Básica } \\
\text { gerou uma } \\
\text { disputa } \\
\text { acirrada } \\
\text { entre os } \\
\text { gestores. A } \\
\text { supervaloriz } \\
\text { ação do } \\
\text { número } \\
\text { /indicador } \\
\text { produzido, } \\
\text { o desgaste } \\
\text { físico, } \\
\text { emocional e } \\
\text { financeiro } \\
\text { prejudicam } \\
\text { a ação } \\
\text { pedagógica } \\
\text { e } \\
\text { desumaniza } \\
\text { os autores } \\
\text { desse } \\
\text { processo. }\end{array}$ \\
\hline 11 & $\begin{array}{l}\text { OBREQUEI, } \\
\text { A. S; } \\
\text { HERNÁNDE } \\
\text { Z, C; PEÑA, } \\
\text { S; AGREDO, }\end{array}$ & $\begin{array}{l}\text { Evaluation of } \\
\text { teacher } \\
\text { performance }\end{array}$ & $\begin{array}{l}\text { https://doi.org/10.1590/1 } \\
\underline{98053145792}\end{array}$ & $\begin{array}{l}\text { Teacher } \\
\text { evaluation; } \\
\text { Perception; } \\
\text { Basic } \\
\text { education; }\end{array}$ & $\begin{array}{l}\text { jun. } \\
2019 .\end{array}$ & $\begin{array}{l}\text { Os } \\
\text { professores } \\
\text { de sentiram } \\
\text { afetados } \\
\text { emocionalme } \\
\text { nte, }\end{array}$ \\
\hline
\end{tabular}

Ferreira et al. 


\begin{tabular}{|c|c|c|c|c|c|c|}
\hline & $\begin{array}{l}\text { M; } \\
\text { TROYANO, } \\
\text { A; } \\
\text { SALVATIER } \\
\text { RA, M. O; } \\
\text { CÁCERES, B }\end{array}$ & $\begin{array}{l}\text { In Chile: } \\
\text { perception of } \\
\text { poorly } \\
\text { Evaluated } \\
\text { teachers }\end{array}$ & & Chile. & & $\begin{array}{l}\text { criticaram a } \\
\text { falta de } \\
\text { tempo e } \\
\text { apoio durante } \\
\text { o sua atuação } \\
\text { na escola } \\
\text { onde } \\
\text { trabalham. } \\
\text { Os autores } \\
\text { sugerem que } \\
\text { os } \\
\text { responsáveis } \\
\text { pelas } \\
\text { tomadas de } \\
\text { decisões } \\
\text { tenha acesso } \\
\text { aos resultado } \\
\text { das } \\
\text { avaliações. }\end{array}$ \\
\hline 12 & $\begin{array}{l}\text { FERRAZI, A. } \\
\text { S; SANTOS, } \\
\text { A. A. A; } \\
\text { ALMEIDA, L. } \\
\text { S }\end{array}$ & $\begin{array}{l}\text { Escala de } \\
\text { Atribuições de } \\
\text { Causalidade e } \\
\text { Rendimento } \\
\text { Escolar: } \\
\text { Estudo de } \\
\text { Evidência de } \\
\text { Validade de } \\
\text { Critério }\end{array}$ & $\begin{array}{l}\text { https://doi.org/10.21814/ } \\
\text { rpe.14279 }\end{array}$ & $\begin{array}{l}\text { Atribuição } \\
\text { causal; } \\
\text { Motivação } \\
\text { para a } \\
\text { aprendizage } \\
\text { m; } \\
\text { Ensino } \\
\text { Básico; } \\
\text { Avaliação } \\
\text { psicoeducaci } \\
\text { onal. }\end{array}$ & $\begin{array}{l}08 / 06 / 20 \\
19\end{array}$ & $\begin{array}{l}\text { A Escala de } \\
\text { Avaliação } \\
\text { das } \\
\text { Atribuições } \\
\text { de } \\
\text { Causalidade } \\
\text { para Alunos } \\
\text { do Ensino } \\
\text { Fundamental } \\
\text { (EAVAT- } \\
\text { EF), leva os } \\
\text { estudantes a } \\
\text { refletir sobre } \\
\text { os fatores que } \\
\text { influenciam } \\
\text { no } \\
\text { rendimento } \\
\text { escolar, é } \\
\text { importante } \\
\text { salientar que } \\
\text { as meninas se } \\
\text { identificaram } \\
\text { mais com o } \\
\text { tipo de } \\
\text { avaliação em } \\
\text { análise. }\end{array}$ \\
\hline 13 & $\begin{array}{l}\text { GIROTTO, } \\
\text { Eduardo } \\
\text { Donizeti (2019 }\end{array}$ & $\begin{array}{l}\text { Pode a política } \\
\text { pública } \\
\text { mentir? } \\
\text { A base } \\
\text { nacional } \\
\text { comum } \\
\text { curricular } \\
\text { e a disputa da } \\
\text { qualidade } \\
\text { educacional }\end{array}$ & $\begin{array}{l}\text { https://doi.org/10.1590/e } \\
\underline{\text { s0101-73302019207906. }} .\end{array}$ & $\begin{array}{l}\text { Currículo. } \\
\text { Reforma } \\
\text { educacional. } \\
\text { Desigualdad } \\
\text { es. }\end{array}$ & $\begin{array}{l}23 / 09 / 20 \\
19\end{array}$ & $\begin{array}{l}\text { O contexto } \\
\text { educacional } \\
\text { atual está } \\
\text { enfrentado } \\
\text { uma crise } \\
\text { existencial } \\
\text { que a } \\
\text { BNCC não } \\
\text { pode } \\
\text { resolver. } \\
\text { Cada } \\
\text { governo } \\
\text { com seus } \\
\text { interesses e } \\
\text { a sociedade } \\
\text { tentando } \\
\text { produzir } \\
\text { resultados } \\
\text { que elevem }\end{array}$ \\
\hline
\end{tabular}

Ferreira et al. 


\begin{tabular}{|c|c|c|c|c|c|c|}
\hline & & & & & & $\begin{array}{l}\text { o status dos } \\
\text { mesmos. }\end{array}$ \\
\hline 14 & $\begin{array}{l}\text { OLIVEIRA, P; } \\
\text { LACERDA, } \\
\text { C. B. F }\end{array}$ & $\begin{array}{l}\text { The historical } \\
\text { track of studies } \\
\text { and } \\
\text { research on } \\
\text { dyslexia: the } \\
\text { search } \\
\text { for the } \\
\text { understanding } \\
\text { of the } \\
\text { phenomenon }\end{array}$ & $\begin{array}{l}\underline{\text { http://dx.doi.org/10.2392 }} \\
\underline{5 / 2176-} \\
\underline{2724.2018 v 30 i 4 p 791-}\end{array}$ & $\begin{array}{l}\text { Dyslexia; } \\
\text { Learning } \\
\text { Disorder; } \\
\text { Special } \\
\text { Education; } \\
\text { Education; } \\
\text { Learning } \\
\text { Disabilities; } \\
\text { Educational } \\
\text { Evaluation } \\
\text { Avaliação } \\
\text { Educacional. }\end{array}$ & $\begin{array}{l}\text { DEZ.20 } \\
18\end{array}$ & $\begin{array}{l}\text { A inclusão } \\
\text { ainda não } \\
\text { saiu do } \\
\text { papel. E a } \\
\text { dislexia } \\
\text { ainda é } \\
\text { tratada } \\
\text { como } \\
\text { doença, } \\
\text { sendo o } \\
\text { estudante o } \\
\text { responsável } \\
\text { pelo seu } \\
\text { desenvolvi } \\
\text { mento. }\end{array}$ \\
\hline 15 & $\begin{array}{l}\text { CRAVO, F. A. } \\
\text { M; } \\
\text { ALMEIDA, } \\
\text { A. C. M }\end{array}$ & $\begin{array}{l}\text { Avaliação de } \\
\text { desempenho } \\
\text { escolar após } \\
\text { exposição a } \\
\text { um programa } \\
\text { informatizado } \\
\text { de leitura e } \\
\text { escrita }\end{array}$ & $\begin{array}{l}\text { https://doi.org/10.5935/2 } \\
\underline{175-3520.20180012}\end{array}$ & $\begin{array}{l}\text { leitura; } \\
\text { Escrita; } \\
\text { Educação } \\
\text { especial; } \\
\text { Sala de } \\
\text { recursos; } \\
\text { Avaliação. }\end{array}$ & $\begin{array}{l}2^{\circ} \\
\text { semestre } \\
\text { de } 2018\end{array}$ & 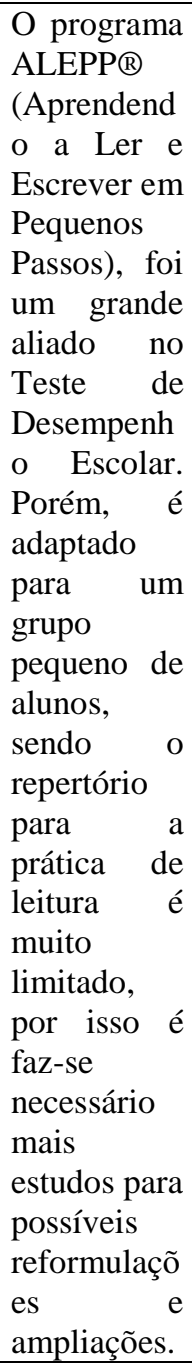 \\
\hline 16 & $\begin{array}{l}\text { VIEIRA, M. } \\
\text { N. A; CÔCO, } \\
\text { V }\end{array}$ & $\begin{array}{l}\text { Avaliação } \text { e } \\
\text { Currículo na } \\
\text { Educação } \\
\text { Básica: a } \\
\text { especificidade } \\
\text { da Educação } \\
\text { Infantil }\end{array}$ & $\begin{array}{l}\underline{\text { https://doi.org/10.5212/P }} \\
\underline{\text { raxEduc.v.11i3.0016 }}\end{array}$ & $\begin{array}{l}\text { Avaliação } \\
\text { institucional. } \\
\text { Currículo. } \\
\text { Educação } \\
\text { Infantil. }\end{array}$ & $\begin{array}{l}21 / 03 / 20 \\
17\end{array}$ & $\begin{array}{l}\text { Faz-se } \\
\text { necessário } \\
\text { ainda maior } \\
\text { investiment } \\
\text { o na } \\
\text { formação } \\
\text { inicial e } \\
\text { continuada } \\
\text { de } \\
\end{array}$ \\
\hline
\end{tabular}

Ferreira et al. 


\begin{tabular}{|c|c|c|c|c|c|c|}
\hline & & & & & & $\begin{array}{l}\text { professores, } \\
\text { pois a } \\
\text { prática } \\
\text { avaliativa } \\
\text { está } \\
\text { totalmente } \\
\text { desarticulad } \\
\text { o com o } \\
\text { planejament } \\
\text { o com a } \\
\text { prática } \\
\text { pedagógica } \\
\text { e com os } \\
\text { embasamen } \\
\text { tos teóricos } \\
\text { e legais. }\end{array}$ \\
\hline 17 & $\begin{array}{l}\text { PEREIRA, } \\
\text { Rodrigo da } \\
\text { Silva }\end{array}$ & $\begin{array}{l}\text { Avaliação de } \\
\text { sistemas e } \\
\text { política de } \\
\text { competências } \\
\text { e habilidades } \\
\text { da OCDE }\end{array}$ & $\underline{\underline{\text { https://doi.org/10.5212/P }}}$ & $\begin{array}{l}\text { Evaluation } \\
\text { of } \\
\text { Educational } \\
\text { systems. } \\
\text { Pisa. } \\
\text { Competence } \\
\text { s and skills. } \\
\text { OCDE. } \\
\text { Basic } \\
\text { Education. }\end{array}$ & $\begin{array}{l}28 / 11 / 20 \\
17\end{array}$ & $\begin{array}{l}\text { A } \\
\text { Organizaçã } \\
\text { o para a } \\
\text { Cooperação } \\
\text { e o } \\
\text { Desenvolvi } \\
\text { mento } \\
\text { Econômico } \\
\text { (OCDE) } \\
\text { contribui } \\
\text { para a } \\
\text { implemataç } \\
\text { ão de } \\
\text { polítcas } \\
\text { públicas que } \\
\text { visem a } \\
\text { melhoria da } \\
\text { educação, } \\
\text { entre elas, a } \\
\text { política de } \\
\text { sistema de } \\
\text { avalição. }\end{array}$ \\
\hline 18 & $\begin{array}{l}\text { UNTERHAL } \\
\text { TER, } \\
\text { Elaine }\end{array}$ & $\begin{array}{l}\text { The Many } \\
\text { Meanings of } \\
\text { Quality } \\
\text { Education: } \\
\text { Politics of } \\
\text { Targets and } \\
\text { Indicators in } \\
\text { SDG41 }\end{array}$ & $\begin{array}{l}\text { https://doi.org/10.1111/1 } \\
758-5899.12591\end{array}$ & $\begin{array}{l}\text { Growth } \\
\text { mindset } \\
\text { pedagogy; } \\
\text { Growth } \\
\text { mindset; } \\
\text { Fixed } \\
\text { mindset; } \\
\text { Case study; } \\
\text { Stimulated } \\
\text { recall } \\
\text { interview; } \\
\text { Finland. }\end{array}$ & $\begin{array}{l}28 / 01 / 20 \\
19\end{array}$ & $\begin{array}{l}\text { É possível } \\
\text { garantir } \\
\text { através da } \\
\text { mobilização } \\
\text { social uma } \\
\text { educação } \\
\text { gratuita, } \\
\text { inclusiva, } \\
\text { de } \\
\text { qualidade e } \\
\text { igualitária } \\
\text { conforme a } \\
\text { meta } 4 \\
\text { (ODS) e } 2 \\
\text { (ODM), que } \\
\text { resumem no } \\
\text { SGD4. }\end{array}$ \\
\hline 19 & CAVIEDES, & $\begin{array}{l}\text { Trabajo } \\
\text { docente } \\
\text { políticas } \\
\text { De evaluación } \\
\text { externa en }\end{array}$ & $\frac{\text { http://dx.doi.org/10.1722 }}{\underline{7 / \text { rce.num77-6497. }}}$ & $\begin{array}{l}\text { Política } \\
\text { educacional; } \\
\text { calidad }\end{array}$ & $\begin{array}{l}2^{\circ} \\
\text { semestre } \\
2019\end{array}$ & $\begin{array}{l}\text { Apresenta a } \\
\text { contradição } \\
\text { entre o que é } \\
\text { proposto, } \\
\text { como }\end{array}$ \\
\hline
\end{tabular}

Ferreira et al. 


\begin{tabular}{|c|c|c|c|c|c|c|}
\hline & & $\begin{array}{ll}\text { Colombia } & y \\
\text { Brasil } & \end{array}$ & & $\begin{array}{l}\text { de la } \\
\text { educación; } \\
\text { indicadores } \\
\text { educativos; } \\
\text { evaluación } \\
\text { de la } \\
\text { educación; } \\
\text { responsabili } \\
\text { dad } \\
\text { del docente }\end{array}$ & & $\begin{array}{l}\text { atribuição } \\
\text { ao professor } \\
\text { e as más } \\
\text { condições } \\
\text { de trabalho } \\
\text { que lhe é } \\
\text { dada. }\end{array}$ \\
\hline 20 & $\begin{array}{l}\text { NOGUEIRA, } \\
\text { G. M; } \\
\text { PRADO, G. O }\end{array}$ & $\begin{array}{l}\text { A avaliação na } \\
\text { Educaçâo } \\
\text { Infantil: uma } \\
\text { análise a partir } \\
\text { de relatórios } \\
\text { de uma } \\
\text { Professora }\end{array}$ & $\begin{array}{l}\text { http://doi.org/10.5212/Pr } \\
\underline{\text { axEduc.v.11i3.0017 }}\end{array}$ & $\begin{array}{l}\text { Avaliação. } \\
\text { Educação } \\
\text { Infantil. } \\
\text { Relatórios } \\
\text { de avaliação. }\end{array}$ & $\begin{array}{l}\text { Dez/ } \\
2016\end{array}$ & $\begin{array}{l}\text { A educação } \\
\text { básica } \\
\text { abrange a } \\
\text { educação } \\
\text { infantil. As } \\
\text { rianças } \\
\text { devem ser } \\
\text { tratadas } \\
\text { como } \\
\text { sujeitos de } \\
\text { direito, } \\
\text { capazes de } \\
\text { produzir } \\
\text { cultura. E a } \\
\text { avaliação } \\
\text { deve ser } \\
\text { contínua. O } \\
\text { que não } \\
\text { ocorreu com } \\
\text { esta } \\
\text { professora. }\end{array}$ \\
\hline 21 & AMARO & $\begin{array}{l}\text { As políticas de } \\
\text { avaliação em } \\
\text { larga escala e } \\
\text { trabalho } \\
\text { docente: dos } \\
\text { discursos } \\
\text { eficientistas } \\
\text { aos caminhos } \\
\text { contrarregulat } \\
\text { órios }\end{array}$ & $\begin{array}{l}\text { http://dx.doi.org/10.2172 } \\
\underline{\text { 3/riaee.v11.n4.7155 }}\end{array}$ & $\begin{array}{l}\text { Políticas de } \\
\text { avaliação. } \\
\text { Trabalho } \\
\text { docente. } \\
\text { Caminhos } \\
\text { contraregula } \\
\text { tórios. }\end{array}$ & 2016 & $\begin{array}{l}\text { Todo } \\
\text { processo } \\
\text { avaliativo } \\
\text { deve estar } \\
\text { vinculado } \\
\text { aos } \\
\text { objetivos, } \\
\text { finalidades } \\
\text { e contexto } \\
\text { da educação, } \\
\text { caso isso } \\
\text { não ocorra é } \\
\text { tido como } \\
\text { contrarregul } \\
\text { atório. } \\
\end{array}$ \\
\hline 22 & 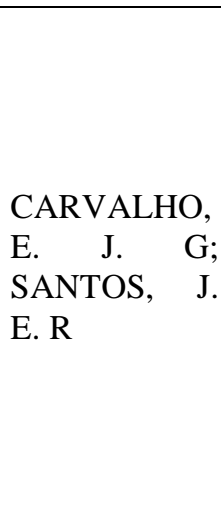 & $\begin{array}{l}\text { Políticas de } \\
\text { avaliações } \\
\text { externas: } \\
\text { ênfase nas } \\
\text { competências } \\
\text { cognitivas e } \\
\text { socioemociona } \\
\text { is }\end{array}$ & $\begin{array}{l}\text { http://doi.org/10.5212/Pr } \\
\underline{\text { axEduc.v.11i3.0014 }}\end{array}$ & $\begin{array}{l}\text { Políticas } \\
\text { educacionais } \\
\text {. Avaliações } \\
\text { externas. } \\
\text { Competênci } \\
\text { as }\end{array}$ & $\begin{array}{l}\text { Dez/ } \\
2016\end{array}$ & $\begin{array}{l}\text { A avaliação } \\
\text { externa é } \\
\text { um } \\
\text { instrumento } \\
\text { excludente, } \\
\text { promove a } \\
\text { desigualdad } \\
\text { e e a } \\
\text { disputa, } \\
\text { indicando } \\
\text { quem é mais } \\
\text { ou menos } \\
\text { competente. }\end{array}$ \\
\hline
\end{tabular}

Ferreira et al. 


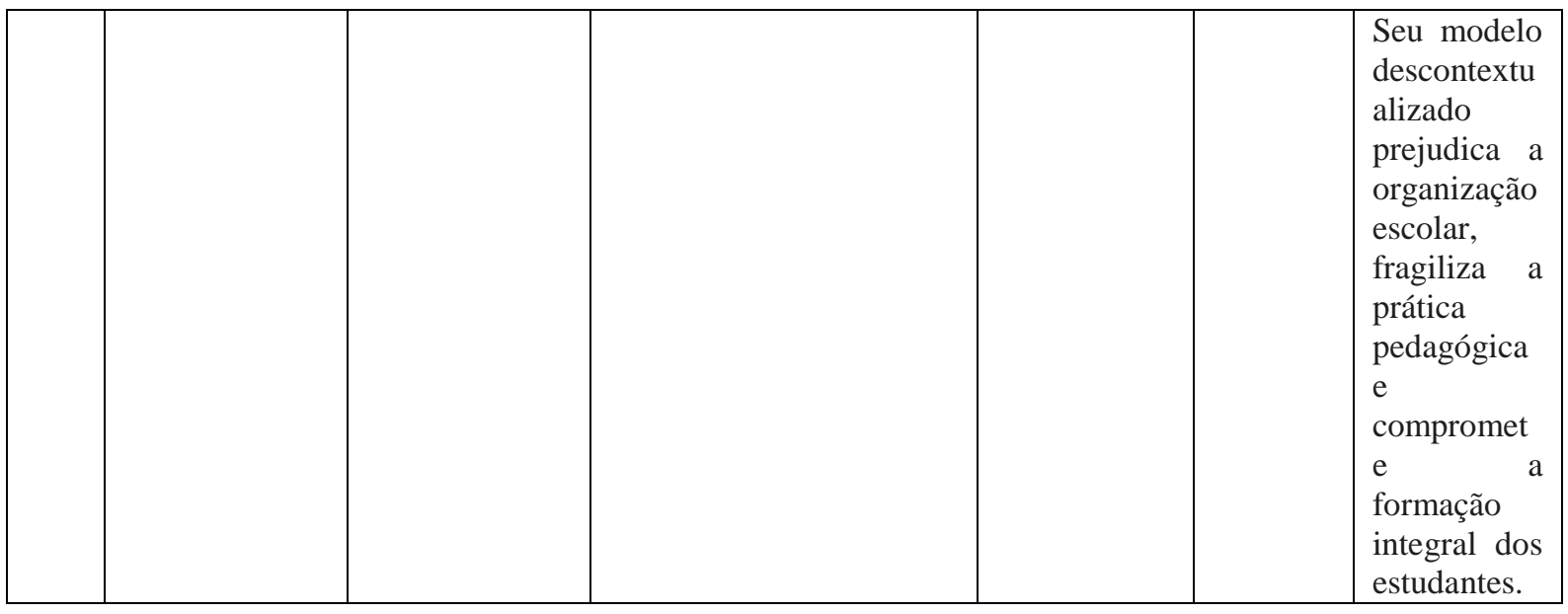

Fonte: Autoria própria.

\section{DISCUSSÃO}

Através dessa revisão bibliográfica foi possível analisar e entender como como ocorre a avaliação educacional sob vários ângulos, como por exemplo, nas unidades de ensino, da prática pedagógica, do desempenho dos alunos, da educação básica, do ensino superior, de métodos e sistemas e da aprendizagem. A temática se desenvolveu com base nas categorias: avaliação institucional, avaliação em larga escala e concepções sobre avaliação.

\section{Avaliação educacional}

Inúmeros projetos e programas têm sido desenvolvidos para combater os baixos índices escolares, apesar de participar pontualmente da agenda avaliativa proposta pelo Ministério da Educação, o Brasil ainda não conseguiu detectar o problema que fragiliza do processo de ensino aprendizagem da escola pública. Hoje, a avaliação é o eixo norteador das principais discussão sobre qualidade educacional ela deve ser também mola mestra para o planejamento de ações, metas e práticas significativas e apontar verdadeiros padrões de qualidade.

Avaliar por competências e habilidades tem gerado grandes discussões no meio científico e pedagógico, ao verificar o perfil dos estudantes de cada região é possível detectar que há uma discrepância, aumentando as críticas em relação ao padrão avaliativo do Ministério da Educação, preestabelecido pelo INEP. Essa assertiva se fortalece mais com a implantação da BNCC, que traz um rol de conteúdos programáticos sob a orientação que devem ser adaptados de acordo com a territorialidade de cada unidade escolar.

Girotto (2019) destaca que a BNCC é um documento norteador, estruturado para desenvolver competências e habilidades objetivando a formação integral dos alunos através dos princípios éticos, políticos e 
estéticos, mas está totalmente desarticulado com do contexto educacional brasileiro. $\mathrm{O}$ aluno contemporâneo está bem informado e domina as tecnologias como propõe a BNCC, deve ser desenvolvida nos estudantes a cultura digital ela é a quinta competência geral, visa desenvolver habilidades como a compreensão, o uso e a criação de novas tecnologias de forma crítica, significativa e ética. Mas o que que se tem na maioria das escolas é um corpo docente averso à tecnologia e a qualquer metodologia inovadora.

De acordo com Santos et al. (2017), o uso da tecnologia, como ferramenta pedagógica é uma temática que deve ser repensada, atualizada e posta em prática, oferece aos professores possibilidades de inovação, de práticas significativas, prazerosas e desafiadoras, cumprindo o que propõe a base. Para que essa habilidade seja desenvolvida nos estudantes é necessário que o professor tenha domínio mínimo de ferramentas digitais. Ou seja, é possível detectar que o corpo docente não está preparado para atender as demandas oriundas da sociedade contemporânea, no que diz respeito a tecnologia, e esse fato é por vezes ignorado pelo gestores.

Partindo de um questionário detectaram que o desenvolvimento da cultura digital, e o uso das Tecnologias da Informação e da Comunicação - TICs precisam ser mais valorizados, pois aproximadamente $70 \%$ dos participantes da pesquisa concordam que as ferramentas digitais contribuem positivamente para o processo de autoaprendizagem, para a boa comunicação. Porém, os professores ainda não empregam as TICs no desenvolvimento da ação pedagógica e a maioria dos docentes não consideram a multimídia como seus aliados e sim como uma vilã que pouco contribui no processo de ensino.

Nesse cenário surge a necessidade de um profissional disposto a inovar e experimentar novas ferramentas para gerir um sistema, uma rede, uma escola, uma sala de aula adotando a concepção e o perfil de um gestor educacional onde fosse possível articular o trabalho administrativo e o pedagógico. Um trabalho realizado com a participação de todos, com o foco voltado para a aprendizagem.

Vale salientar a importância do comprometimento de cada indivíduo envolvido, bem como na eficácia e eficiência. Entre os envolvidos há uma figura que é a essência de tudo, o professor, um profissional habilitado e capacitado para produzir conhecimentos e formar cidadãos, por meio de embasamentos teóricos, procedimentos didáticos e pedagógicos. Todos em função daqueles para quem a escola se prepara todos os dias, abrindo os portões, oferecendo segurança, higienizando o ambiente, preparando 
alimentação, fazendo o melhor para atender à necessidade e os anseios de cada um.

Tecendo uma abordagem sobre desempenho profissional os autores Obrequei et al. (2019) expõem o Programa de Melhoria Profissional e detectam que apesar de toda preparação e clareza os professores se sentiram inseguros diante de uma avaliação. Ao observar os professores durante 0 processo registrou comportamento como egoísmo ao silenciarem após a avaliação, outros se apresentaram passivamente empáticos com os pares e a maioria demonstrou uma forte aversão ao processo avaliativo. Através da coleta de dados foram detectados pontos como desgaste emocional, falta de apoio e falta de tempo para preparar material e documentos, pontos que precisam ser debatidos e analisados para manter a melhoria profissional e a qualidade da educação.

Com o objetivo de avaliar a leitura e a escrita, Cravo et al. (2018) analisaram um programa de intervenção ALEPP $\AA$ Aprender a Ler e Escrever em Pequenos Passos (a pesquisa foi desenvolvida no Laboratório de Aprendizagem Desenvolvimento e Saúde -UNESP), que faz parte do Instituto Nacional de Ciência e Tecnologia sobre Comportamento, Cognição e Ensino, com recursos da FAPESP (Processo2014/50909-8) e do CNPq (Processo No. 465686/2014-1) com o objetivo de medir o desempenho escolar, a realização do TDE - Teste de Desempenho Escolar, o resultado foi satisfatório, mas o banco de atividades é muito resumido e atende a um grupo pequeno de estudantes, os autores sugerem um estudo mais aprofundado para futuras reformulações no sentido de ampliar ALEPP®.

Outra avaliação que exige a participação dos envolvidos é o conselho escolar, evidenciando que avaliar não é excluir, segundo os autores Oliveira et al. (2018) a participação no conselho escolar deve ser planejada, coletiva, efetiva e acompanhada de muita responsabilidade, com o atenção redobrada ao avaliar, para não correr o risco de cometer injustiça e exclusão.

Wallenius et al..(2018) tratam de forma global sobre a avaliação da qualidade educacional (EQA), também abordam a deficiência na formação crítica do cidadão e da capacidade de escolher bem os governantes, cita o modelo de governo da Suécia, Dinamarca e Noruega, os governos lançaram portais da web, nos quais vários indicadores podem ser observados e comparados, cada escola recebe seu resultado, já na Finlândia, os dados são publicados apenas em nível geral o que dificulta a observação, análise e o desenvolvimento de ações direcionadas para cada realidade. A partir da estrutura do institucionalismo discursivo elaboraram 
uma entrevista e aplicaram aos especialistas em educação, a fim de identificar como se dá a discussão em relação ao resultado do processo avaliativo nos países nórdicos, tendo como eixo norteador a garantia e Avaliação da Qualidade Educacional EQA, através do Programa Internacional de Avaliação de Estudantes - PISA.

Os resultados e a ações desenvolvidas para alcanças as metas precisam ser discutidos e socializados, levando em consideração as particularidades de cada país. Porém, a Finlândia divulga seu resultado apenas globalmente, vive em constante trabalho para atingir as melhores posições.

Essa discussão gira em torno da competência global, um estimulo a competição e comparações; um discurso neoliberal defendendo, o aumento de testes, para escolas e aluno de forma individual e um discurso escolar nórdico abrangente, destacando igualitarismo nórdico, uma oposição ao neoliberalismo.

O Programa Internacional de Avaliação dos Alunos - Pisa, financiado pela Organização para Cooperação e Desenvolvimento Econômico - OCDE, foi o foco na pesquisa de Pereira (2017) enfatiza uma avaliação por competências e habilidades, onde os países participantes são atraídos por propostas de políticas de crescimento econômico e mão de obra qualificada no mercado de trabalho. Em
1995 o Brasil iniciou o monitoramento do sistema educacional, criou a Avaliação Nacional da Educação Básica - ANEB, a Avaliação Nacional de Rendimento Escolar - ANRESC, conhecida como Prova Brasil, ambas constituem o Sistema de Avaliação da Educação Básica - SAEB.

O Brasil marca a sua participação na PISA desde 2000, com a obrigação de compartilhar e divulgar a ideologia implantada pela OCDE, inclusive ser avaliado de forma global. De forma ampla também se destaca o Programa Internacional de Avaliação dos Alunos Pisa, financiado pela Organização para Cooperação e Desenvolvimento Econômico -OCDE, a pesquisa realizada por Pereira (2017) faz várias críticas ao modelo de avaliação baseado em competências e habilidades, tendo em vista as diferenças culturais e as condições que são oferecidas aos participantes.

Os países que constituem essa organização são atraídos por propostas de políticas de crescimento econômico e mão de obra qualificada no mercado de trabalho. O Brasil realiza avalições educacionais desde 1995, e participa do PISA desde a sua primeira edição em 2000, com a obrigação de divulgar a ideologia implantada pela OCDE. A escola é um símbolo de acessão social, a globalização acentuou ainda mais esse conceito sobre a escola. Uma nação escolarizada tem mão obra qualificada no 
mercado de trabalho, desenvolve grandes pesquisas e projetos humanitários é bem desenvolvida em todos os aspectos, principalmente, no campo científico, político e financeiro

O que se observa é um longo percurso avaliativo percorrido pelos sistemas e redes de ensino e nada mudou de 1950 até os dias atuais, pois é evidente que o fim da avalição é a produção de números para representar a qualidade do ensino. Uma avalição que gera competição baseada no mito da meritocracia, cujo objetivo é exaltar os que obtém o resultado projetado e excluir impiedosamente aqueles que falta de condições não atingem as metas previstas pelos sistemas de ensino.

\section{Avaliação em larga escala ou externa}

Nos últimos 20 anos o Brasil vem sendo controlado por esse modelo opressor e excludente de avaliação, as escolas adotam um ritual pedagógico mecanizado de treinamento e da troca de treino intensivo por brindes e premiações. Os premiados são sempre os mesmos alunos e professores, os demais contam com a sorte, mas logo que o aplicador corrige o exame detecta, imediatamente, contradições como que o estudante não conseguiu assinar o nome, nem preencheu a data de nascimento, mas fez uma pontuação alta.

Tendo como ponto de partida a projeção de metas estabelecidas nos planos nacional, estadual, municipal e no plano de ação institucional, são estabelecidas algumas ações vislumbrando atingir um resultado previsto. Para cada um dos planos, há uma instância responsável que coordena e articula todo o processo. Neste sentido não há nada mais gratificante do que atingir e divulgar os números positivos produzidos através das avaliações externas aplicadas $\operatorname{nos} 3^{\circ}, 5^{\circ}, 9^{\circ}$ e $3^{\circ}$ médio, estudantes no último período do ensino superior. É notória a valorização das equipes escolares que conseguem elevar alguns pontos percentuais no IDEB e a decepção e exclusão dos que não atingem um resultado satisfatório. Pois o resultado produzido é o principal indicador da qualidade do ensino, ou seja, o sucesso ou fracasso do sistema, da rede, da escola, do aluno.

A avaliação deveria ser uma aliada da educação, mas da forma que acontece ela é simplesmente uma classificação em um pódio, evidenciada na forma impositiva da participação das unidades de ensino através dos modelos padronizados e da avaliação por competências e habilidades. Esse modelo que impõe, tem em vista os anseios da hegemonia, imobiliza a sociedade, fere o senso crítico e a cidadania. Isso se confirma na falta de autonomia e na impossibilidade de se elaborar modelos avaliativos condizentes com, no mínimo, cada região brasileira. 
É necessário uma mudança de concepção em relação ao modelo atual de avaliação externa, e de suma importância saber qual a finalidade da avaliação, sabendo que avaliar não é punir, nem excluir e sim para se obter melhorias e o sucesso escolar. Síveres, et al. (2018) apresentam a implementação da avaliação institucional e afirmam que para que haja mudança é fundamental que sejam partilhadas entre todos os envolvidos as prioridades, a necessidade, a clareza, a complexidade, a qualidade e a praticidade da inovação, toda a comunidade escolar precisa compreender a finalidade e a importância da mudança a partir da uma avaliação, neste caso a participação é um grande aliado. "Desse modo, o desafio da avaliação institucional é também o desafio da gestão democrática nas escolas" (SÍVERES, L; SANTOS, J, R, R, 2018, p.

De acordo com a pesquisa de Souza et al. (2018), o resultado das avaliações externas não é sinônimo de qualidade, os autores afirmam que o Sistema de Avaliação da Educação Básica - SAEB é uma disputa injusta, que exige dos participantes muito sacrifício e submissão, é importante salientar que o resultado das avaliações externas é também uma forma de o governo fiscalizar e cobrar dos gestores municipais e escolares o uso dos recursos financeiros destinados à educação.
Para Amaro (2016), avaliar em larga escala não contribui para melhorias de qualidade educacional, é uma negociação, um acerto de contas, quem produzir mais números, torna-se herói quem produz pouco, o vilão. Muitas vezes o herói, é especialista em camuflagem, e independente de qual posição se ocupa, toda essa ação resulta em desgaste dos profissionais, desperdício de recursos financeiros, fuga dos documentos e embasamentos legais e a fragilização ação pedagógica. Diante disso, é gerada uma inquietação cultural, pois um país constituído por 26 estados e um distrito federal faz uso de um padrão, único, para avaliar toda a educação, sem levar em consideração a situação e as especificidades do público a ser avaliado. A avaliação serve para transformar a realidade da instituição escolar, sem comparações, ou preconceitos, eliminando toda concepção de exclusão.

Em seu artigo Unterhalter (2019) discorre sobre educação de qualidade para todos, prevista na meta 4 nos Objetivos de Desenvolvimento do Milênio - ODM, na meta 2, universalização da educação, prevista no Plano Nacional da EducaçãoPNE e da importância da ONU e UNESCO em relação aos indicadores de qualidade educacionais. A autora expõe que qualidade não se demonstra apenas com números, mesmos que estes gerem recursos e status, discorre também, sobre a 
importância de alcançar metas, mas alerta a sociedade para que se informe e verifique se de fato a qualidade é presente nas ações dos sistemas, da rede, da escolas e da sala de aula. É fundamental uma avaliação para se identificar quais são os indicadores, se precisam ser debatidos, repensados ou reformulados e como eles realmente refletem na qualidade da educação.

Os autores Carvalho \& Santos (2016) e Caviedes (2019) defendem que a avaliação externa ou em larga escala tem pontos negativos que precisam ser postos em debate, tecem uma crítica ao modelo avaliativo aplicado no Brasil, no Chile e na Colômbia. Entre os pontos negativos estão as comparações, por sinal, infundadas, o que é feito com esse resultado após a avaliação e como é divulgado. Os mesmos apontam que esse tipo de avaliação não condiz com a realidade, apenas precariza o trabalho desenvolvido na sala de aula. Diante disso é necessário que se desenvolva uma concepção e se construa um modelo de avaliação voltada para a realidade de cada região ou estado.

Nos últimos anos as equipes gestoras estão sendo movidas pelo termo meritocracia, isso tem causado um grande desgaste, de acordo com o dicionário Aurélio significa "predomínio numa sociedade, organização, grupo, ocupação etc. daqueles que têm mais méritos (os mais trabalhadores, mais dedicados, mais bem dotados intelectualmente etc.)", a meritocracia tem como princípios regras que são previamente estabelecidas e conhecidas de todos os participantes, sendo importante estabelecer uma situação que garanta igualdade de oportunidades e condições para todos naquela circunstância. Ao analisar essa concepção, é possível perceber que se vive uma falso reconhecimento pelos meritocratas, causando injustiça ao estabelecer metas imaginando que todos os estudantes brasileiros têm a mesma condição social, econômica e cultural.

É importante destacar que nas manchetes de jornais, noticiários, documentários e demais veículos de informação são divulgado dados lides enfatizando a desescolarização dos brasileiros e a desqualificação profissional. Mas não é comum assistirmos o que foi feito para que essa realidade fosse superada, uma vez que existem indicadores que levam ao detalhamento desse diagnóstico e apontamentos para as devidas soluções.

É contraditório pessoas externas avaliarem contextos distintos, a partir de um modelo padronizado, baseado no desenvolvimento de competências e habilidades, como leitura interpretação e resolução de problemas, em alunos que mal conseguem escrever o próprio nome, mas que precisam ser treinados para participar de um exame com a responsabilidade de 
produzir um resultado satisfatório. E se esse resultado não acontece é transferido automaticamente o fracasso aos professores e alunos, sendo importante destacar que nenhum ser humano quer carregar um título de fracassado. Mas é o que acontece logo após a divulgação dos resultados.

\section{Algumas concepções sobre avaliação}

Diante da reforma do ensino superior, após a criação do Programa de Avaliação e Reforma Universitária - PARU, desenvolvido pela CAPES de 1983 a 1985 e do Programa de Avaliação Institucional do Brasil, - PAIUB, ocorreram várias mudança. No que diz respeito a avaliação, Gomes \& Melo (2018) abordam em sua pesquisa, a implementação de avaliação institucional e avaliação de cursos e de desempenho profissional, destacaram a rede pública e a rigorosidade nas regras e critérios de avaliação. Em 1995 o PAIUB, foi substituído pelo Exame Nacional para Avaliação de Cursos - ENC, conhecido como provão. Foi alvo de muitas críticas, pois um dos critérios para receber o diploma era a participação nesta avaliação.

Mais adiante foi criado um novo modelo de avaliação o Sistema Nacional Avaliação do Ensino Superior - SINAES, que passa a analisar as instituiçõos, cursos e desempenho dos alunos, considerando aspectos como como ensino, pesquisa, extensão, responsabilidade social, gestão institucional e professores, a partir de informações do Exame Nacional de Desempenho dos Estudantes - ENAD, realizado pelo INEP- Instituto Nacional de Estudos e Pesquisas Educacionais Anísio Teixeira. São variadas nomenclaturas, mas o objetivo é o mesmo fiscalizar, controlar os sistemas de educação e limitar a autonomia institucional.

Não basta esperar periodicamente, por uma avaliação externa para obter indicadores de qualidade, é possível inserir na rotina escolar a prática avaliativa, abrangendo a gestão, os professores e alunos, adotando uma concepção fundamentada nos resultados obtidos, replanejando as ações tendo em vista a superação das dificuldades diagnosticadas.

Um pesquisa realizada por Ferrazi et al. (2019) apresenta A Evidência de Validade de Critério para a Escala de Avaliação das Atribuições de Causalidade para Alunos do Ensino Fundamental EAVAT- E F, é um projeto que tem como objetivo combater a reprovação e o fracasso escolar, sua eficiência foi confirmada, os alunos conseguiram atribuir a si mesmos a causa de repetência, principalmente, os do fundamental II. Esse trabalho foi feito em alunos portugueses e brasileiros e reação foi semelhante entre os dois públicos. A auto percepção foi um dos pontos importantes no que diz respeito a avaliação, os autores chamam a atenção para o que consideram 
como um desafio que é não produzir nos alunos excesso de atribuições, pois eles precisam também ser motivados para reverter o histórico negativo de repetência.

Vieira et al. (2017) defendem a avaliação com base no currículo da educação infantil e faz uso de amplo arcabouço teórico e legal. Para avaliar na educação infantil é necessário que o professor conheça e seja crítico diante qualquer contradição que venha dificultar a sua prática pedagógica e aprendizagem das crianças. Citam ainda que como a educação infantil é parte da educação básica, seria justo e necessário ser avaliada. Assim, o Ministério da Educação, também produziria indicadores de qualidade da educação infantil e possivelmente seriam projetadas melhorias para este segmento.

Nogueira et al. (2016) traçam um histórico embasado entre nas Diretrizes Curriculares Nacionais para a Educação Infantil - DCEI. A pesquisa foi realizada por meio de análise documental objetivando entender qual a concepção de avaliação adotada pela professora. Foram analisados relatórios dos alunos, neles foram encontraram muitas lacunas como o uso de

\section{CONSIDERAÇÕES FINAIS}

Com base na Constituição Federal (1988), a escola é um direito de todos, deve formar cidadãos críticos e qualificados para linguagem coloquial, relatos apenas do que a professora desenvolveu faltando a ação dos alunos, descrição do desenvolvimento cognitivo do aluno como: conhece o alfabeto, conta a dez, e a maioria escrito em primeira pessoa do plural. Diante da análise foi detectado que a professora não tem o hábito de registro diário deixando explícito que o primeiro semestre não foi registrado no tempo previsto. $\mathrm{O}$ instrumento escolhido foi um portfólio que tem como objetivo registrar as ações desenvolvidas pelos estudantes e reflexões acerca do processo de ensino aprendizagem, mas o instrumento não atingiu a sua função, pois o que predominou foi a avaliação quantitativa.

Seja na educação básica ou no ensino superior é fundamental que se tenha consciência sobre a importância da avaliação, não basta avaliar para descobrir a dificuldade dos estudantes, ou falhas na gestão, ou para apontar a incoerência nas políticas avaliativas. É imprescindível ter em mente que a avaliação está a favor da melhoria do ensino aprendizagem e da busca incansável para atingir mais alto grau de qualidade.

o trabalho. Diante disso surgem os indicadores de qualidade educacionais e devem estar concatenados com planos (nacional, estadual, municipal, institucional), com as condições de ensino 
que são ofertadas, com a gestão e organização escolar, formação inicial e continuada de profissionais, prática pedagógica e sucesso ou fracasso escolar. Todos os tipos e intenções de avaliação são criteriosamente sistematizados, exigindo do professional o conhecimento básico sobre a temática e sobre os avaliados.

A pesquisa realizada tem como objetivo identificar as dificuldades existentes no processo de avaliação e a incoerência de transformar competências e habilidades em números. Foi detectado também, uma forte crítica aos modelos padronizados e descontextualizados e impostos pela hegemonia das políticas públicas nacionais e internacionais.

A arte de formar todos esses profissionais é atribuída e cobrada aos professores, eles formam a classe menos

\section{REFERÊNCIAS}

SÍVERES, L; SANTOS, J. R. R, Avaliação Institucional na Educação básica: Os desafios da Implementação. Est. Aval. Educ., São Paulo, v. 29, n. 70, p. 222-253, jan./abr. 2018.

SANTOS, T. P; ALVES, M. P. O contributo das tecnologias no desenvolvimento do currículo escolar: perspectivas dos alunos. Revista IberoAmericana de Estudos em Educação, v.12, n. esp. 2, p. 1554-1569, ago./2017.

SOUZA, R.R; COLARES, A. A. A avaliação em larga escala nos centros educacionais de tempo integral: mais tempo, melhores resultados? Educação: reconhecida e valorizado no mercado de trabalho. São eles que presenteiam a sociedade e se orgulham grandemente por ter contribuído com o crescimento da ciência de da nação. Há uma sobre carga gigantesca nas mãos dos docentes, fazendo com que muitos terminem sua carreira inválidos ou desacreditados na grandiosidade do exercício de sua função.

Portanto, a revisão bibliográfica realizada, constata que, para a avaliação, atingir de fato seu objetivo, que seria avaliar e diagnosticar a qualidade da educação, é indispensável relacionar aspectos qualitativos, quantitativos, sociais, econômicos e culturais, assim, quem avaliar, poderá subsidiar a formulação de projetos, programas e políticas públicas que favoreçam, efetivamente o processo de ensino e aprendizagem

Teoria e Prática/ Rio Claro, SP/ Vol. 27, n. 56, p. 511 - 525, SETEMBRODEZEMBRO, 2017

SANTOS, F. A; PETOUR, M. T. F. Internacionalização dos sistemas de avaliação: evidências de brasil e chile. RIAEE - Revista Ibero-Americana de Estudos em Educação, Araraquara, v. 14, n. esp. 3, p. 1829-1846, out., 2019.

OLVERA, A. C; GUTIÉRREZ, J. A. L; LOZANO, M. E. E. C. Los consejos técnicos escolares para la inclusión y equidad educativa en la educación básica de Tlaxcala, México. Revista Electrónica Educare (Educare Electronic Journal) EISSN: 1409-4258 Vol. 22(1) ENEROABRIL, 2018. 
PINTO, M. L; JUNG, H. S. y;

SUDBRACK, E. M. Evaluation Policies

and Educational Management:

articulations, interfaces and tensions.

Revista Electrónica de Investigación

Educativa, 21, 2019.

WALLENIUS, T; JUVONEN, S;

HANSEN, P; VARJO, J. Schools, accountability and Transparency

approaching the Nordic school evaluation practices through discursive institutionalism. Nordic Journal of Studies in Educational Policy, 4:3, 133-143, 2018.

ALMEIDA, M. L. P; JUNG, H. S;

SUDBRACK, E. M. Políticas

educacionales brasileñas: consecuencias de un currículo nacional. Revista Electrónica de Investigación Educativa, 21, 2019.

FILHO, O. O; SÁ, V. I. M.Avaliação externa da gestão escolar do Programa Nova Escola do Estado do Rio de Janeiro: um estudo reflexivo sobre o seu primeiro ciclo de realização (2000-2003), passados quinze anos de sua implementação. Ensaio: aval. pol. públ. Educ., Rio de Janeiro, v.24, n. 91, p. 275-307, abr./jun. 2016.

FIGUEIREDO, D; CARMO, E; MAIA, R.; SILVA. L. Os cavalos também caem: Tratado das inconsistências do IDEB. Ensaio: aval. pol. públ. Educ., Rio de Janeiro, v.26, n.100, p. 552-572, jul./set. 2018.

OBREQUEI, A. S; HERNÁNDEZ, C; PEÑA, S; AGREDO, M; TROYANO, A; SALVATIERRA, M. O; CÁCERES, B. Evaluation of teacher performance In Chile: perception of poorly Evaluated teachers. Cad. Pesqui., São Paulo, v.49 n.172 p.144163 abr./jun. 2019.

FERRAZI, A. S; SANTOS, A. A. A; ALMEIDA, L. S. Escala de Atribuições de Causalidade e Rendimento Escolar: Estudo de Evidência de Validade de Critério.
Revista Portuguesa de Educação, 32(1), pp. 125-139. 2019.

GIROTTO, E. D. Pode a política pública mentir? A base nacional comum curricular e a disputa da qualidade educacional. Universidade de São Paulo - São Paulo (SP), Brasil. Educ. Soc., Campinas, v.40, e 0207906, 2019.

CRAVO, F. A. M; ALMEIDA, A. C. M. Avaliação de desempenho escolar após exposição a um programa informatizado de leitura e escrita. Psic. da Ed., São Paulo, 47, pp. 1-10, 20 sem. de 2018.

VIEIRA, M. N. A; CÔCO, V Avaliação e Currículo na Educação Básica: a especificidade da Educação Infantil. Práxis Educativa, Ponta Grossa, p. 812-831, v. 11, n. 3, set./dez. 2016.

PEREIRA, Rodrigo da Silva Avaliação de sistemas e política de competências e habilidades da OCDE. Práxis Educativa, Ponta Grossa, v. 13, n. 1, p. 107-127, jan./abr. 2018

UNTERHALTER, Elaine. The Many Meanings of Quality Education: Politics of Targets and Indicators in SDG41. Global Policy, Volume 10. Supplement 1, January 2019.

CAVIEDES, Juan Francisco Remolina. Trabajo docente y políticas De evaluación externa em Colombia y Brasil. Revista Colombiana de Educación, 77, 2019.

NOGUEIRA, G. M; PRADO, G. O. A avaliação na Educação Infantil: uma análise a partir de relatórios de uma Professora. Práxis Educativa, Ponta Grossa, p. 832849, v. 11, n. 3, set./dez. 2016.

AMARO, Ivan. As políticas de avaliação em larga escala e trabalho docente: dos discursos eficientistas aos caminhos contrarregulatórios. RIAEE - Revista Ibero- 
Americana de Estudos em Educação, v. 11, n. 4, p. 1960-1978, 2016.

CARVALHO, E. J. G; SANTOS, J. E. R. Políticas de avaliações externas: ênfase nas competências

cognitivas

e socioemocionais. Práxis Educativa, Ponta Grossa, p. 775-794, v. 11, n. 3, set./dez. 2016 